\title{
An Integrated Information System to Support Supply Chain Management \& Performance in SMEs
}

\author{
Dekeng S. Budiarto ${ }^{1}$ (D), M. Agung Prabowo ${ }^{2}$ iD, Tutut Herawan $^{3}$ \\ ${ }^{1}$ Universitas PGRI Yogyakarta (Indonesia) \\ ${ }^{2}$ Universitas Sebelas Maret Surakarta (Indonesia) \\ ${ }^{3}$ AMCS Research Institute (Indonesia) \\ dekengsb@upy.ac.id, muhammadagung@staff.uns.ac.id, tutut@amcs.co
}

Received: November 2016

Accepted: February 2017

\section{Abstract:}

Purpose: This study aims to examine the relation between the level of supply chain management (SCM) adoption and small \& medium enterprises (SMEs) performance. SCM adoption level it is expected to facilitate SMEs in improving their efficiency, thus they can obtain their competitive advantage.

Design/methodology/approach: This study uses primary data in the form of questionnaires. This study only takes the SMEs engaged in commerce (retail) business in order to avoid bias in IT usage. The questionnaires are given to 88 SMEs owners whom responsible for the IT development in their companies.

Findings: The result proves that SCM adoption significantly affects SMEs performance. The hypotheses testing is performed using one-way ANOVA, the result shows that there are significant differences between level initiation, diffusion, and integration with SMEs performance.

Originality/value: This study explains the relation between supply chain management (SCM) adoption level and SMEs performance that has never been performed before.

Keywords: initiation, diffusion, integration, supply chain management, performance, SMEs 


\section{Background}

Technology integration can improve management quality of a company (Lari, 2002) and also suppressing the inefficiencies caused by poor supplier performance, unpredictable customer demand, and uncertain business environment (Lenny-Koh, Demirbag, Bayraktar, Tatoglu \& Zaim, 2007). Thus, technology integration process among company, supplier, and customer is an important part of Supply Chain Management (SCM). SCM is an application, which is also part of IT, by utilizing IT, SMEs will be more competitive in facing the competition. One of the SCM purposes is IT adoption to integrate and connecting the supply chain partner (Chou, Tan \& Yen, 2004; Pieter van Donk, Bakker, Zheng, Knight \& Harland, 2008; Ou, Liu, Hung \& Yen, 2010; Yee-Loong-Chong, Ooi, Bao \& Lin, 2014). SCM becomes very important because the quality of goods or services produced will depend on the selection of suppliers quality whom providing goods and services (Lenny-Koh et al., 2007; Yee-Loong-Chong, Ooi, Lin \& YiTang, 2009). Moreover, SCM adoption is very interesting because of the SMEs limitation, such as lack of skill, lack of knowledge, and lack of information technology (Rahman, Wasilan, Deros \& Ghani, 2011).

Study focusing on IT implementation in SMEs is still interesting even though it is already conducted multiple times (Urquía-Grande, Pérez-Estébanez \& Muñoz-Colomina, 2011). This research aims to study the IT implementation in Indonesian SMEs, because; 1) based on the government data, in 2015 SMEs contributes $60.34 \%$ of the economic development; 2) $97.22 \%$ of Indonesian labors are absorbed by SMEs; 3) the prior findings which explain that SMEs have a limitation in IT implementation (Chen, Papazafeiropoulou \& Wu, 2012; Jones, Beynon-Davies, Levy, Powell \& Yetton, 2011) and performance measurement (Gunasekaran, Putnik, Sousa, Aspinwall \& Guimarães-Rodrigues, 2006). Thus, the result can give a great contribution to the SMEs owners and the government in the IT implementation planning thus SMEs performance will improve.

In addition, of testing the relation between IT adoption level and SCM, this study is also testing the relation between IT adoption level and SMEs performance. The prior findings explain that supply chain integration can be seen from supplier-customer perspective (Gimenez, van der Vaart \& Pieter van Donk, 2012) and internal perspective (Flynn, Huo \& Zhao, 2010). This study will be testing the supply chain integration from IT adoption level perspective (internal) because internal integration has a greater influence on performance (Flynn et al., 2010).

Therefore, this research is done to answer whether SCM adoption levels has an impact on SMEs performance, and also is there any significant difference between SCM adoption levels on SMEs performance. The result can be used as a reference for the researcher whom interested with IT adoption in SMEs topic, and also provides a feedback for the SMEs owners in selecting technology appropriates to the needs. 


\section{Literature Review and Hypotheses Development}

Model developed in this study shown in Figure 1. Figure 1 shows the relation between IT adoption level with SCM and the relation between SCM with SMEs performance. The further explanation of IT adoption level with SCM and SMEs performance will be presenting in the next subsection. Further, the literature review and hypotheses will be developing based on the relevant prior studies.

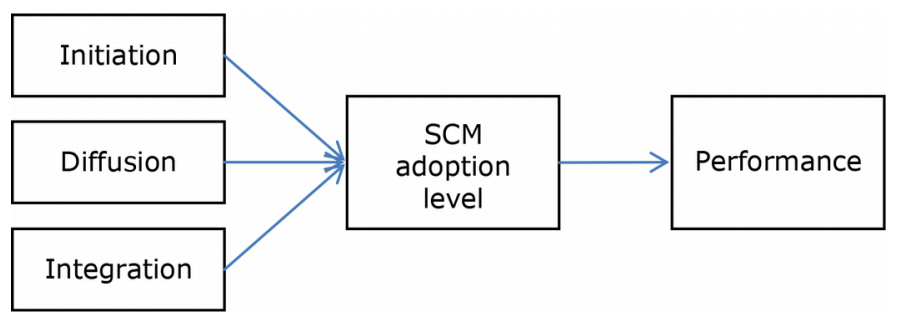

Figure 1. Level of adoption SCM and performance

This research model (Figure 1) is development from previous research. Hussin, King and Cragg (2002) explained that IT implementation on SMEs can be categorized into three levels such as initiation, diffusion and integration. Those levels would determine the successfully of IT implementation, the higher of IT adoption, the easier IT implementation. Other research (Yen-Teoh \& Pan, 2009; Ou et al., 2010; Simon \& Petnji-Yaya, 2012) stated that IT integration on SMEs will increase the performance thus the higher SCM integration levels, the better of SMEs performance.

\subsection{Level of Adoption SCM and Performance}

The supply chain concept is theorized from the formation of value chain network consisting of individual functional entities committed to providing resources and information to achieve the objectives of efficient management of suppliers as well as the flow of part (Lau \& Lee, 2000; Lenny-Koh et al., 2007). SCM becomes very interesting when it relates to integration process in the company. Beside the customer-supplier integration, internal integration is also an important factor. In supply chain context, internal integration can improve the collaboration quality between company partner internal management of company to increase the company value (Tumaini \& Zheng, 2011). Supply chain integration can be explained into 3 categories, they are operational integration, functional integration and relational integration. However other than those 3 categories, the appropriate technology usage is also important 
(New \& Westbrook, 2004; Gimenez et al., 2012). Company with appropriate and integrated technology will be easier in adopting SCM. The results of previous finding have presented in Table 1.

A central objective of effective SCM is to create a major source of competitive advantage for the enterprise to differentiate itself in the eyes of the costumers from its competitors by operating at lower cost and hence at greater profit (Christopher 1999; Lenny-Koh et al., 2007). To achieve this goal SMEs need an integrated technology to support SCM in order to improve the company efficiency (Chen et al., 2012; Rahman et al., 2011). Flynn et al. (2010) and Ou et al. (2010) find an evidence of SCM practice relates to firm performance. However, other studies explain that supply chain integration will improve firm performance if the supply complexity is high. When the firm faces variant demands from the consumer, supply chain integration is needed, thus internal coordination can be performed properly (Gimenez et al., 2012).

\begin{tabular}{|l|l|l|}
\hline \multicolumn{1}{|c|}{ Researchers } & \multicolumn{1}{|c|}{ Samples/Countries } & \multicolumn{1}{c|}{ Finding } \\
\hline Gimenez et al. (2012) & $\begin{array}{l}\text { 145 SME in Spain and } \\
\text { Netherland }\end{array}$ & $\begin{array}{l}\text { SCM integration increases performance if supply } \\
\text { complexity is high, while a very limited on low complexity }\end{array}$ \\
\hline $\begin{array}{l}\text { Yee-Loong-Chong et al. } \\
(2009)\end{array}$ & 138 SMEs in Malaysia & $\begin{array}{l}\text { Inter-organizational relationships were affecting Malaysian } \\
\text { SMEs' decision to adopt e-business in the supply chain }\end{array}$ \\
\hline Ou et al. (2010) & 95 firms in Taiwan & $\begin{array}{l}\text { External customer-firm-supplier relation management } \\
\text { positively impacts firm internal contextual factors, which in } \\
\text { turn have positive impact on firm performance }\end{array}$ \\
\hline Lenny-Koh et al. (2007) & 203 SMEs in Turkey & $\begin{array}{l}\text { SCM practices with outsourcing and multi-supplier (OMS) } \\
\text { and strategic collaboration and lean practices (SCLP) have } \\
\text { significant impact on operational performance }\end{array}$ \\
\hline Flynn et al. (2010) & $\begin{array}{l}\text { 617 manufacturing firms in } \\
\text { China }\end{array}$ & $\begin{array}{l}\text { The findings of both the contingency and configuration } \\
\text { approach indicated that supply chain integration was related } \\
\text { to both operational and business performance }\end{array}$ \\
\hline $\begin{array}{l}\text { Söderberg and Bengtsson } \\
\text { (2010) }\end{array}$ & $\begin{array}{l}\text { 15 SMEs in Sweden } \\
\text { The results indicate that there is a strong relationship } \\
\text { between SCM maturity and SC performance in SMEs and } \\
\text { some relationships between SCM maturity and financial } \\
\text { performance }\end{array}$ \\
\hline Tumaini and Zheng (2011) & 229 SMEs in Tanzanian & $\begin{array}{l}\text { The study found that SMEs still face obstacles like } \\
\text { knowledge, financial resources and technology }\end{array}$ \\
\hline
\end{tabular}

Table 1. Previous finding in different countries

IT integration is an important need for SMEs because IT integration will produce precise information that can improve firm efficiency, customer satisfaction, and firm productivity (Volkoff, Strong \& Elmes, 2005; Berente, Vandenbosch \& Aubert, 2009; Sampaio, Saraiva \& Domingues, 2012; Francalanci \& Morabito, 2008; Yen-Teoh \& Pan, 2009; Simon \& Petnji-Yaya, 2012). Thus, the more integrated the information system, the better the firm performance. Based on the literature review, the hypotheses can be proposed as follow: 


\section{$H_{1}: S C M$ adoption significantly affects firm performance}

\section{$\mathrm{H}_{2}$ : There is significant difference between SCM adoption level with firm performance}

\section{Research Methodology}

\subsection{Sample and Data Collection}

The populations in this study are all owners of SMEs in retail sector that implemented IT in Yogyakarta. Based on the data from Industrial, Trades, Cooperation, and SMEs Agency, the number of SMEs in Yogyakarta is 1.429 for all type of business. The number of retail SMEs are about 25\%. This research focus on retails field due to they used more IT than another. This study uses questionnaires to collect the data from respondents. The respondents in this study are 300 retail SMEs owner whom utilize IT transaction. The questionnaires are gives along with the introduction to make sure that respondent's responses are confidential and will be uses for research purpose only. A purposive sampling technique have adopted in this study with specific characteristic, the selection of the sample based on the judgment about some appropriate characteristic requires of the sample members (Zikmund, 2000). The SMEs characteristic is according to the Law No. 20 of 2008 regarding SMEs, with SMEs criteria as follows: the maximum annual turnover amount is 2.5 billion IDR, the maximum amount of total assets is 200.000 .000 IDR, the number of employee are 5-19 for small enterprises and 20-99 for medium enterprises. Before the questionnaires are given to the respondents, a pretest is conducted with students and the SMEs owners as the respondents, and then the questionnaires are modified to make sure that the questions are understandable. Within the estimated time, 108 questionnaires returned, 20 questionnaires cannot be processed because they do not contain a complete data needed (the respondents did not answer some questions), 88 questionnaires can be analyzed further with the response rate of $29 \%$.

\subsection{Measurement of Variables}

The measurement of SCM and SMEs performance uses instrument that derived from earlier research, but adapted to make it suitable for population of this study. According to the prior study (Hussin et al., 2002) IT adoption consists of 3 levels: initiation, diffusion, and integration. Initiation level shows a small number of IT users; much autonomy is given to users; and little amount of efforts in planning and controlling the existing systems. Diffusion level shows IT adoption performed by large number of users; rapid growth of expenditure on IT hardware, software, and personnel; and planning and controlling the system is still conducted informally. Integration level shows IT application is more integrated; more 
control procedures are introduced; and planning of application is better established. Respondents will be asked to choose one of these levels that represent the IT adoption in their firm.

In the beginning, SCM variable is measured with 12 questions, but after a trial is conducted with the retail SMEs owners, only 7 questions are used because it is the most appropriate with the condition and the most understandable. The question items including close partnership with supplier; close partnership with customer; just in time supply; e-procurement; outsourcing, subcontracting; Third-party logistic; strategic planning; supply chain benchmarking; few suppliers; many suppliers; and holding safety stock (Li, Rao, Ragu-Nathan \& Ragu-Nathan, 2005; Lenny-Koh et al., 2007). The responses are scaled with 5 point, from $1=$ are not implemented to $5=$ implemented well.

Empirical study explains that performance measurement in SMEs has many variations (Lenny-Koh et al., 2007). Performance variable in this study is measures with four questions according to the SMEs owners' assessments of their firm performance compared with their competitor performance. The four questions related to long-term profitability; availability of financial resources; sales growth; image; and client loyalty (Khandwalla, 1977; Ismail \& King, 2005). These measurements are use because it is more objective and appropriate for SMEs context (Miller, 1987; Raymond, Paré \& Bergeron, 1995; Cragg, King \& Hussin, 2002; Ismail \& King, 2005). 


\section{Result and Discussion}

\subsection{Respondent Demography}

The result shows that $22.7 \%$ of the SMEs have been operate for more than 10 years, $30.7 \%$ of the SMEs have been operate for 5-10 years, and the other $46.6 \%$ have been operated for $<5$ years. Most of the SMEs are in initiation level (50\%); $27.3 \%$ of them are in diffusion level; and $22.7 \%$ of them are in integration level. Sixty six percent of the SMEs have $<20$ employees and the other $43 \%$ have $20-50$ employees (Table 2).

\begin{tabular}{|c|c|c|}
\hline Profile of respondent & Number of SMEs & Percentage ( $\%)$ \\
\hline (1) & (2) & (3) \\
\hline $\begin{aligned} & \text { Company age: } \\
& 1 .<5 \text { years } \\
& 2 . 5-10 \text { years } \\
& 3 .>10 \text { years }\end{aligned}$ & $\begin{array}{l}41 \\
27 \\
20\end{array}$ & $\begin{array}{l}46.6 \\
30.7 \\
22.7\end{array}$ \\
\hline 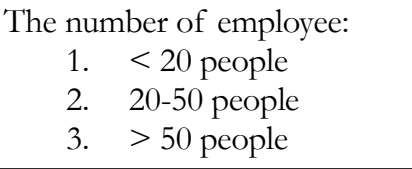 & $\begin{array}{r}50 \\
38 \\
0\end{array}$ & $\begin{array}{r}56.8 \\
43.2 \\
0\end{array}$ \\
\hline 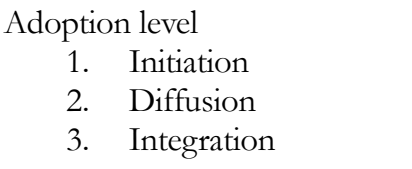 & $\begin{array}{l}44 \\
24 \\
20\end{array}$ & $\begin{array}{l}50.0 \\
27.3 \\
22.7\end{array}$ \\
\hline $\begin{aligned} \text { Type of } & \text { business } \\
\text { 1. } & \text { Phone store } \\
\text { 2. } & \text { Minimarket } \\
\text { 3. } & \text { Drugstore } \\
\text { 4. } & \text { Computer store }\end{aligned}$ & $\begin{array}{l}30 \\
24 \\
18 \\
16\end{array}$ & $\begin{array}{l}34.1 \\
27.3 \\
20.5 \\
18.2\end{array}$ \\
\hline
\end{tabular}

Table 2. Respondent demography

\subsection{Validity and Reliability Testing}

To avoid error in the variable measurement, validity and reliability test is performed. Validity test is performed to find if the instruments appropriately measure the variable. The validity test is performed using Pearson correlation with significance rate of 5\%. After the validity test, reliability test is performed to ensure the consistency of the responses (Hair, Anderson, Babin \& Black, 2010). The reliability test is performed using Cronbach's Alpha coefficient with the minimum limit of 0.6.

The result of validity test on SCM variable (Table 3) shows that all the instruments are valid with $p$ value $<1 \%$. The result also shows that all the instruments of SCM variable can be used in the next analysis. The instrument testing for performance (Table 4) shows that the instruments for: long-term profitability, availability of financial resources, sales growth; image, and client loyalty are valid with $p$ value $<1 \%$. The 
reliability test result shows that all the instruments used are reliable with Cronbach's Alpha coefficient $>$ 0.6. The reliability test result gained the Cronbach's Alpha coefficient of 0.728 for SCM and 0.675 for performance.

\begin{tabular}{|c|l|c|}
\hline No. & \multicolumn{1}{|c|}{ Instrument } & Pearson correlation \\
\hline 1. & e-procurement & $0.551^{* *}$ \\
\hline 2. & JIT supply & $0.726^{* *}$ \\
\hline 3. & Many suppliers & $0.655^{* *}$ \\
\hline 4. & Holding safety stock & $0.625^{* *}$ \\
\hline 5. & Strategic planning & $0.588^{* *}$ \\
\hline 6. & Close partnership with customers & $0.460^{* *}$ \\
\hline 7. & Close partnership with suppliers & $0.557^{* *}$ \\
\hline 8. & Supply chain benchmarking & $0.517^{* *}$ \\
\hline
\end{tabular}

** Significant at $p<1 \%$

Table 3. Validity test of SCM variable

\begin{tabular}{|c|l|c|}
\hline No. & \multicolumn{1}{|c|}{ Instrument } & Pearson correlation \\
\hline 1. & Long-term profitability & $0.754^{* *}$ \\
\hline 2. & Availability of financial resources & $0.681^{* *}$ \\
\hline 3. & Sales growth & $0.726^{* *}$ \\
\hline 4. & Image and client loyalty & $0.713^{* *}$ \\
\hline
\end{tabular}

** Significant at $p<1 \%$

Table 4. Validity test of performance measurement variable

\subsection{Mean Value Testing}

This study aims to test the relationship between SCM adoption level and SMEs performance. In the first step, mean analysis will be conducting on SCM instruments (Table 5) to understand the respondent perception. 


\begin{tabular}{|c|c|c|c|c|c|c|c|}
\hline \multirow{2}{*}{ No. } & \multirow{2}{*}{ Items } & \multicolumn{2}{|c|}{ Initiation } & \multicolumn{2}{|c|}{ Diffusion } & \multicolumn{2}{|c|}{ Integration } \\
\hline & & Mean & S. Dev. & Mean & S. Dev. & Mean & S. Dev. \\
\hline 1. & e-procurement & 3.75 & 0.651 & 4.00 & 0.659 & 4.55 & 0.605 \\
\hline 2. & JIT supply & 3.80 & 0.701 & 4.08 & 0.717 & 4.55 & 0.510 \\
\hline 3. & Many suppliers & 3.82 & 0.657 & 4.13 & 0.797 & 4.50 & 0.607 \\
\hline 4. & Holding safety stock & 3.59 & 0.726 & 3.96 & 0.624 & 4.20 & 0.616 \\
\hline 5. & Strategic planning & 3.77 & 0.605 & 4.13 & 0.612 & 4.30 & 0.470 \\
\hline 6. & Close partnership with customers & 4.07 & 0.545 & 4.21 & 0.588 & 4.50 & 0.513 \\
\hline 7. & Close partnership with suppliers & 4.09 & 0.563 & 4.33 & 0.482 & 4.50 & 0.513 \\
\hline 8. & Supply chain benchmarking & 4.16 & 0.745 & 4.46 & 0.658 & 4.80 & 0.410 \\
\hline
\end{tabular}

Table 5. SCM adoption level

Table 5 shows that on the initiation level, the mean value is in the range of 3.59-4.16, while on the integration level the mean value is in the range of 4.20-4.80. Mean value testing shows that SMEs owners in the integration level have a higher perception on SCM adoption than SMEs owners in the initiation level. For example, mean value of close partnership with supplier indicator is 4.09 on initiation level; 4.33 on diffusion level; and 4.50 on integration level.

\subsection{Hypotheses Testing}

Regression testing is use to test the Hypothesis 1, the effect of independent variable (SCM) on the dependent variable (performance). The regression analysis result is show on Table 6.

\begin{tabular}{|c|c|c|}
\hline Independent variables & Beta & Sig. \\
\hline Supply chain management & 0.380 & $0.000^{* *}$ \\
\hline $\begin{array}{l}F: 14.533 \\
R^{2}: 0.145\end{array}$ & & $0.000^{* *}$ \\
\hline
\end{tabular}

** Significant at $p<1 \%$

Table 6. Regression analysis result

The regression analysis result (Table 6) shows that SCM adoption affects SMEs performance (sig at $\mathrm{p}<1 \%$ ). The determination coefficient shows that $14.5 \%$ of SMEs performance can be explained by SCM. The regression analysis result proves that the better SCM adoption will improve SMEs performance (Hypothesis 1 accepted). 
To test whether there is a significance relation of IT adoption level with SCM, one-way ANOVA analysis is uses with significance of $5 \%$. Each SMEs will be divided into three IT adoption categories, which are initiation, diffusion, and integration. The hypotheses testing result is show on Table 7.

\begin{tabular}{|c|l|r|r|r|r|r|}
\hline No. & \multicolumn{1}{|c|}{ Items } & \multicolumn{1}{c|}{ Initiation } & \multicolumn{1}{c|}{ Diffusion } & Integration & \multicolumn{1}{c|}{ F ratio } & \multicolumn{1}{c|}{ Sig. } \\
\hline 1. & Long-term profitability & 4.18 & 4.46 & 4.65 & 4.842 & $0.010^{*}$ \\
\hline 2. & Availability of financial resources & 3.38 & 4.29 & 4.55 & 7.523 & $0.001^{*}$ \\
\hline 3. & Sales growth & 4.09 & 4.50 & 4.70 & 9.064 & $0.000^{* *}$ \\
\hline 4. & Image and client loyalty & 4.11 & 4.42 & 4.65 & 6.306 & $0.003^{*}$ \\
\hline
\end{tabular}

* Significant at $p<5 \%,{ }^{* *}$ significant at $p<1 \%$

Table 7. SCM adoption level and performance

The testing of Hypothesis 2 (Table 7) proves that there is a significance difference between IT adoption level (initiation, diffusion, integration) and firm performance. The mean testing shows that on the initiation level the mean value is in the range of 3.38-4.18; on the diffusion level the mean value is in the range of 4.29-4.50; and on the integration level the mean value is in the range of 4.55-4.70. It proves that the higher the IT adoption level, the better the SMEs performance. One-way ANOVA testing shows that all the instruments have $p$ value $<0.05$, it means that IT adoption level is relates to firm performance (Hypotheses 2 accepted).

The result shows that SMEs owners have a high perception on IT application and believe that the more integrated the information system use, the easier the cooperation with supplier (Yee-Loong-Chong et al., 2009; Chen et al., 2012). Moreover, more suppliers will be better because the product price will be lower. Integrated SCM can improve service and suppress expense, thus a good relationship between supplier and consumer can be bound (Archer, Hong \& Jeong, 2006). On the integrated SCM level, partnership strategy development with supplier will be easier to conduct. With this condition, supplier can help SMEs to anticipate a dynamic consumer needs (Flynn et al., 2010).

A good internal integration shows that all the activities and systems are doing their function flexibly. Joint planning, cross-functional teams, and working together are important parts of integration process, thus the firm can provide all consumer needs (Söderberg \& Bengtsson, 2010; Gimenez et al., 2012). A high integration will facilitate a networking with other SMEs, expedite the communication, collaboration, and benchmarking, thus the information exchange related to supplier quality can be done (Yee-Loong-Chong et al., 2009; Knudsen, 2013). Integrated information about IT can accelerate the information delivery that drives SCM to response the market demands quickly and create efficiencies that can ultimately reduce 
costs, improve the firm image in the consumers view, and improve firm performance (Archer et al., 2006; Flynn et al., 2010; Zhang, Yin, Zhang \& Nie, 2014).

\begin{tabular}{|l|r|r|r|}
\hline \multicolumn{1}{|c|}{ SCM } & Initiation * Diffusion & Diffusion * Integration & Initiation * Integration \\
\hline Long-term profitability & 0.197 & 0.846 & $0.012^{*}$ \\
\hline Availability of financial resources & 0.052 & 0.669 & $0.001^{*}$ \\
\hline Sales growth & $0.018^{*}$ & 0.755 & $0.000^{* *}$ \\
\hline Image and client loyalty & 0.130 & 0.568 & $0.003^{*}$ \\
\hline
\end{tabular}

* Significant at $p<5 \%$, ** significant at $p<1 \%$

Table 8. Bonferroni test between adoption level groups and performance

The $F$ test significance on one-way ANOVA testing cannot show the differences of each IT adoption level. Thus, Bonferroni post hoc comparison test (Table 8) is uses to find the differences of each group. The test result shows that only sales growth indicator is significant difference on initiation level and diffusion level. On diffusion and integration level there is no significant difference on all of the performance measurement. This result shows that IT adoption level differences in SMEs are according to the performance measurement indicators.

\section{Conclusion and Implication}

The result shows that IT adoption level relates to SCM adoption. On the integrated level, SMEs will be easier to connect with their supplier and consumer. The information will be easier to obtain and the firm will be fast adapted with the dynamic consumer needs (Archer et al., 2006). The next finding shows that the higher of IT adoption level, the better the firm performance. This finding is consistent with the finding of prior studies (Flynn et al., 2010; Gimenez et al., 2012). This finding is important because prior studies do not examine the IT adoption level as a part of SCM.

This study offers a number of research and managerial implications. First, the result of this study should give other researchers confidence to measure SCM adoption level and SMEs performance using a similar measurement. Second, the results of this study should provide other researchers urge to explore further issues related to SCM barriers in developing countries (Rahman et al., 2011). Third, SMEs owners can utilize the appropriate IT, thus SCM can be perform more efficiently. Fourth, aside from its relation with SCM, IT adoption level also related to the firm performance, thus SMEs owners needs to pay a special 
attention to IT adoption. Fifth, because of these findings are from SMEs context, thus governmental support is needed so SCM adoption can be done more efficiently (Chen et al., 2012).

\section{Limitation and Suggestions for Future Research}

This study has some limitations, first, this study only examines the relationship between IT adoption level with SCM and performance. The future research can connect varied contextual factors, such as country of origin and type of industry (Lenny-Koh et al., 2007). Second, this study has not measured the supplier and customer complexity. The future research can develop a research model that consider customer and supplier complexity because the high integration is not always needed and useful (Gimenez et al., 2012). This study is only conduct in Indonesia, one of the developing countries. Because the IT development level is different in each country, other researcher whom interested with IT development concept in SMEs, can examine IT implementation based on the amount of IT investment, culture, and sophistication of technology. Third, this study does not examine the firm size, while the firm size can affect the SCM adoption (Ou et al., 2010).

\section{Acknowledgement}

This research is supported by Universitas PGRI Yogyakarta, Indonesia.

\section{References}

Archer, N.P., Hong, P., \& Jeong, J. (2006). Supply chain management practices of SMEs: from a business growth perspective. Journal of Enterprise Information Management, 19(3), 292-302.

https://doi.org/10.1108/17410390610658478

Berente, N., Vandenbosch, B., \& Aubert, B. (2009). Information flows and business process integration. Business Process Management Journal, 15(1), 119-141. https://doi.org/10.1108/14637150910931505

Chen, H., Papazafeiropoulou, A., \& Wu, C. (2012). An e-government initiative to support supply chain integration for small to medium sized enterprises: successes and challenges. ACM SIGMIS Database, 42(4), 63-80. https://doi.org/10.1145/2096140.2096145

Chou, D.C., Tan, X., \& Yen, D.C. (2004). Web technology and supply chain management. Information Management \& Computer Security, 12(4), 338-349. https://doi.org/10.1108/09685220410553550 
Christopher, M. (1999). Logistics and Supply Chain Management: Strategies for Reducing Cost and Improving Service. London: Financial Times/Pitman Publishing. Taylor \& Francis. 294.

Cragg, P., King, M., \& Hussin, H. (2002). IT alignment and firm performance in small manufacturing firms. The Journal of Strategic Information Systems, 11(2), 109-132. https://doi.org/10.1016/S0963-8687(02)00007-0

Flynn, B.B., Huo, B., \& Zhao, X. (2010). The impact of supply chain integration on performance: A contingency and configuration approach. Journal of operations management, 28(1), 58-71.

https://doi.org/10.1016/j.jom.2009.06.001

Francalanci, C., \& Morabito, V. (2008). IS integration and business performance: The mediation effect of organizational absorptive capacity in SMEs. Journal of Information Technology, 23(4), 297-312.

https://doi.org/10.1057/jit.2008.18

Gimenez, C., van der Vaart, T., \& Pieter van Donk, D. (2012). Supply chain integration and performance: the moderating effect of supply complexity. International Journal of Operations \& Production Management, 32(5), 583-610. https://doi.org/10.1108/01443571211226506

Gunasekaran, A., Putnik, G.D., Sousa, S. D., Aspinwall, E. M., \& Guimarães-Rodrigues, A. (2006). Performance measures in English small and medium enterprises: survey results. Benchmarking: an international journal, 13(1/2), 120-134.

Hair, J.F., Anderson, R.E., Babin, B.J., \& Black, W.C. (2010). Multivariate data analysis: A global perspective (Vol. 7). Pearson Upper Saddle River, NJ.

Hussin, H., King, M., \& Cragg, P. (2002). IT alignment in small firms. European Journal of Information Systems, 11(2), 108-127. https://doi.org/10.1057/palgrave/ejis/3000422

Ismail, N.A., \& King, M. (2005). Firm performance and AIS alignment in Malaysian SMEs. International Journal of Accounting Information Systems, 6(4), 241-259. https://doi.org/10.1016/j.accinf.2005.09.001

Jones, P., Beynon-Davies, P., Levy, M., Powell, P., \& Yetton, P. (2011). Contingent dynamics of IS strategic alignment in small and medium-sized enterprises. Journal of Systems and Information Technology, 13(2), 106124. https://doi.org/10.1108/13287261111135963

Khandwalla, P.N. (1977). The design of organizations. 260. New York: Harcourt Brace Jovanovich.

Knudsen, J.S. (2013). The growth of private regulation of labor standards in global supply chains: Mission impossible for Western small-and medium-sized firms? Journal of business ethics, 117(2), 387-398. https://doi.org/10.1007/s10551-012-1527-8 
Lari, A. (2002). An integrated information system for quality management. Business Process Management Journal, 8(2), 169-182. https://doi.org/10.1108/14637150210425126

Lau, H.C., \& Lee, W. (2000). On a responsive supply chain information system. International Journal of Physical Distribution \& Logistics Management, 30(7/8), 598-610. https://doi.org/10.1108/09600030010346242

Lenny-Koh, S.C., Demirbag, M., Bayraktar, E., Tatoglu, E., \& Zaim, S. (2007). The impact of supply chain management practices on performance of SMEs. Industrial Management \& Data Systems, 107(1), 103-124. https://doi.org/10.1108/02635570710719089

Li, S., Rao, S.S., Ragu-Nathan, T., \& Ragu-Nathan, B. (2005). Development and validation of a measurement instrument for studying supply chain management practices. Journal of operations management, 23(6), 618-641. https://doi.org/10.1016/j.jom.2005.01.002

Miller, D. (1987). Strategy making and structure: Analysis and implications for performance. Academy of management journal, 30(1), 7-32. https://doi.org/10.2307/255893

New, S., \& Westbrook, R. (2004). Understanding supply chains: concepts, critiques, and futures. OUP Oxford.

Ou, C.S., Liu, F.C., Hung, Y.C., \& Yen, D.C. (2010). A structural model of supply chain management on firm performance. International Journal of Operations \& Production Management, 30(5), 526-545. https://doi.org/10.1108/01443571011039614

Pieter van Donk, D., Bakker, E., Zheng, J., Knight, L., \& Harland, C. (2008). Putting e-commerce adoption in a supply chain context. International Journal of Operations \& Production Management, 28(4), 313-330. https://doi.org/10.1108/01443570810861543

Rahman, M.N.A., Wasilan, H., Deros, B.M., \& Ghani, J.A. (2011). Barriers of SCM in SMEs. Paper read at Applied Mechanics and Materials.

Raymond, L., Paré, G., \& Bergeron, F. (1995). Matching information technology and organizational structure: an empirical study with implications for performance. European Journal of Information Systems 4(1), 3-16. https://doi.org/10.1057/ejis.1995.2

Sampaio, P., Saraiva, P., \& Domingues, P. (2012). Management systems: integration or addition? International Journal of Quality \& Reliability Management, 29(4), 402-424.

https://doi.org/10.1108/02656711211224857

Simon, A., \& Petnji-Yaya, L.H. (2012). Improving innovation and customer satisfaction through systems integration. Industrial Management \& Data Systems, 112(7), 1026-1043. 
Söderberg, L., \& Bengtsson, L. (2010). Supply chain management maturity and performance in SMEs. Operations Management Research, 3(1-2), 90-97. https://doi.org/10.1007/s12063-010-0030-6

Tumaini, M.K., \& Zheng, Q. (2011). Supply Chain Management (SCM) and Small and Medium-Sized Enterprises (SMEs): Is it a Myth? Paper read at Applied Mechanics and Materials.

Urquía-Grande, E., Pérez-Estébanez, R., \& Muñoz-Colomina, C. (2011). The impact of Accounting Information Systems (AIS) on performance measures: empirical evidence in Spanish SMEs. The International Journal of Digital Accounting Research, 11, 25-43. https://doi.org/10.4192/1577-8517-v11_2

Volkoff, O., Strong, D.M., \& Elmes, M.B. (2005). Understanding enterprise systems-enabled integration. European Journal of Information Systems, 14(2), 110-120. https://doi.org/10.1057/palgrave.ejis.3000528

Yee-Loong-Chong, A., Ooi, K.-B., Bao, H., \& Lin, B. (2014). Can e-business adoption be influenced by knowledge management? An empirical analysis of Malaysian SMEs. Journal of Knowledge Management, 18(1), 121-136. https://doi.org/10.1108/JKM-08-2013-0323

Yee-Loong-Chong, A., Ooi, K.-B., Lin, B., \& Yi-Tang, S. (2009). Influence of interorganizational relationships on SMEs'e-business adoption. Internet Research, 19(3), 313-331. https://doi.org/10.1108/10662240910965379

Yen-Teoh, S., \& Pan, S.L. (2009). Customer-centric relationship management system development: A generative knowledge integration perspective. Journal of Systems and Information Technology, 11(1), 4-23. https://doi.org/10.1108/13287260910932386

Zhang, J.-H., Yin, R.-R., Zhang, J., \& Nie, M.-J. (2014). The profit distribution of supply chain under e-commerce. Discrete Dynamics in Nature and Society. https://doi.org/10.1155/2014/287925

Zikmund, W. (2000). Business Research Methods (6th Ed.). Dryden Press.

Journal of Industrial Engineering and Management, 2017 (www.jiem.org)

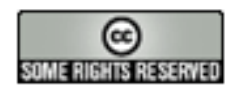

Article's contents are provided on an Attribution-Non Commercial 3.0 Creative commons license. Readers are allowed to copy, distribute and communicate article's contents, provided the author's and Journal of Industrial Engineering and Management's names are included. It must not be used for commercial purposes. To see the complete license contents, please visit http://creativecommons.org/licenses/by-nc/3.0/. 